to allow grant recipients to spend up to 5 per cent of their awards on collabortion with people in Europe and further East could be even more valuable, for such funds are most likely to be spent where collaboration is most likely to flourish. Schemes for keeping ex-Soviet research groups in being with the help of research contracts with commercial organizations in the West - the US Department of Energy and Sun Microsystems are two examples - could be just as valuable, especially if they help to engender more of the commercial sense that Central Europe needs. Sadly, more-academic organizations have been much slower off the mark. Several learned academies have issued statements drawing attention to the need, but have mostly confined themselves to a re-examination of existing exchange schemes. And the chief tangible result of several months of brooding by the larger private foundations (mostly in the United States) has been the decision of the MacArthur Foundation to spend $\$ 3$ million a year and to open an office in Moscow. Is that enough?

\section{Living with monopoly}

Governments everywhere are selling nationalized industries to private persons, but problems of monopoly persist.

THE governments of Central Europe now bent on selling nationalized industries to private investors, but not quite sure how that should be done, might usefully read a series of public documents put out in Britain in the past few weeks. A decade ago, the British government was a pioneer in the field, and may even have been responsible for the word 'privatization'. Now, with the passage of time, it is inevitable that people should be looking back to see how well the job was done. Hindsight gives a somewhat jaundiced view.

So much is clear from what the House of Commons Select Committee on Energy had to say last week about one of the more recent disposals, the sale of the nationalized electricity industry in 1989. The essence of the difficulty is that the electricity industry used to be a strict monopoly - three organizations (two in Scotland) had an exclusive right to generate and sell electricity in their exclusive territories. Part of the case for selling them was the fear that their monopoly rights had made them inefficient. (Another was the need for cash, used to pay off public debt.) But how to create an electricity industry that does not enjoy some kind of monopoly, at least in the sale of kilowatt-hours to those who use them? There is no obvious way.

The British government's solution was to split what was a vertically integrated industry into three horizontal layers - generators of electricity, distributors (who operate the National Grid) and retailers (who deal with the consumers of electricity, but who have the right to generate as well if they choose).

One of the select committee's worries is that the system which has emerged embodies almost no effective compe- tition, but that is hardly a surprise: the retail organizations remain monopolies in their territories, and are regulated by restraints on the prices they are allowed to charge. Moreover, there is a now a tendency for these local monopolies to become more self-contained; there is a fashion for building relatively cheap gas-burning generating sets that will insulate them from the high cost of electricity drawn from the National Grid at times of peak demand. But what else does commercial logic dictate? The committee's worry that the three generating companies (one large, one smaller and one that operates Britain's nuclear capacity) are able to manipulate the prices paid by the National Grid for electricity is more substantial, but may disappear with the passage of time; in principle, at least, anybody believing that electricity can be generated cheaply can join the fray.

This is what seems to be happening with telecommunications, the first substantial privatization in Britain. Although hopes have been disappointed that British Telecom, with more than 90 per cent of Britain's business, would be put under pressure by competition from the company called Mercury, what seems most likely to untie the monopoly knot is last year's decision that the British Telecom network can be used by any provider who wishes, and who is prepared to pay a regulated fee for the privilege. Enough providers of, say, long-distance calls would soon create the pressure on British Telecom that the public interest needs. (Piquantly, still-nationalized British Rail is apparently anxious to enter the lists.)

Meanwhile, there is much that could be done by regulatory fiat. More than a month ago, the industry's regulator, Sir Bryan Carsberg, put out a document reiterating the decision that British Telecom (and others) should be regulated by the prices they actually charge, and not by some other yardstick such as the rate of return on capital. Over the short run, there is force in the argument that price control is the most economic way of keeping monopolies on their toes, and restraining innate rapacity. (Over the longer run, private monopolies have the freedom of knowing that even the toughest regulators are unlikely ever to drive them into bankruptcy.) But Carsberg says he is looking for mechanisms of charging for telecommunications services that will be inherently efficient. Why not simply give all users of, say, telephones, a choice of tariffs allowing them to choose for themselves the proportions of their bills spent on fixed charges and those that are proportional to usage? That way, users would benefit from charges matched more accurately to their needs while the monopoly's capital investment would be more fully used.

In Central Europe, such matters may seem refinements, but they are issues inseparable from the management of private monopolies. Sooner or later, they are inescapable, as the British government has now discovered. And as the United States and Germany (with electricity production) have discovered, it is irrelevant whether the industries concerned begin as nationalized concerns. 